\title{
Pemberdayaan Masyarakat Melalui Agroindustri Ikan Air Tawar Waduk Batu Bulan Di Desa Maman
}

\author{
Rudi Masniadi $^{1}$, Jhon Kenedi ${ }^{2}$, Yudiaihdiansyah ${ }^{3}$ \\ ${ }^{1}$ Fakultas Ekonomi \& Manajemen, Universitas Samawa, Sumbawa, Indonesia \\ ${ }^{2}$ FKIP, Universitas Samawa, Sumbawa, Indonesia \\ ${ }^{3}$ Fakultas Peternakan dan Perkanan, Universitas Samawa, Sumbawa, Indonesia
}

\author{
Article history \\ Received: 25 Desember 2019 \\ Revised: 20 Januari 2020 \\ Accepted: 24 Maret 2020 \\ *Corresponding Author: \\ Rudi Masniadi \\ Fakultas Ekonomi \& \\ Manajemen, Universitas \\ Samawa, Sumbawa, Indonesia; \\ Email: rudimasni@gmail.com
}

\begin{abstract}
Batu Bulan Reservoir, located in Maman Village, Moyo Hulu Subdistrict, Sumbawa Regency, is the longest dam in NTB Province which has high potential for developement. One example is the abundance of fishermen's catches. Furtehermore, the abundant catches result in fish is sold in significantly low prices. Hence, the income of said fishermen in this area is particularly low. It happens due to those fishermen do not have any other option considering their lack of knowledge and skills in processing and preserving their catches for a longer time in order to increase their market value. As far as increasing market value is corncerned, freshly caught fish hold small price in the market for it is raw. If it goes through industrial processes and is transformed into a product of processed fish (agroindustry), of course its market value will rise that in turn will automatically affect its price, consequently will increase the income of the family of fishermen in Maman. The objective of this action is to equip the fishermen in Maman with the necessary skills and knowledge to process their own catches industrially so that it will increase in value and strengthen the local economy. Using the method of training and accompaniment, this activity targets 30 people, which are housewives of fishermen in Maman. The outcome of this program can be assessed with observing the increasing of people of Maman to process fish by $80 \%$. Moreover, two products from this program which are Abon Ikan (Shredded Fish) and Stick Tulang Ikan (Fish Bone Stick) can be realized.
\end{abstract}

Keywords: empowerment; agro-industry

Abtrak: Waduk Batu Bulan terletak di Desa Maman Kecamatan Moyo Hulu Kabupaten Sumbawa, tercatat sebagai bendungan terpanjang di Provinsi NTB yang memilki segenap potensi untuk dikembangkan. Salah satunya adalah melimpahnya hasil tangkapan ikan nelayan. Implikasi lebih jauh dari banyaknya hasil tangkap ini, para nelayan menjual ikannya dengan harga yang relativ murah. Karena harga jual ikan yang murah, maka secara otomatis pendapatan para nelayan relativ rendah. Hal ini dilakukan karena nelayan setempat tidak punya pilihan lain, mengingat masih minimnya pengetahuan dan keterampilan mereka dalam hal pengolahan ikan agar lebih tahan lama dan memilki nilai tambah yang lebih besar. Berbicara dalam konteks peningkatan nilai tambah, ikan hasil tangkapan tentu saja memliki nilai tambah yang sangat rendah karena dijual secara mentah. Padahal jika tersentuh agroindustri, misalnya diolah terlebih dahulu menjadi produk olahan ikan (agroindustri), tentu akan semakin meningkat nilai tambahanya, yang berdampak pada peningkatkan harga jual yang secara otomatis meningkat pendapatan keluarga para nelayan di Desa Maman. Target dari kegiatan ini adalah peningkatan 
pengetahuan dan keterampilan masyarakat Desa Maman tentang metode pengolahan ikan (agroindustri) agar memiliki nilai tambah tinggi, sehingga dapat meningkatkan pendapatan masyarakat dan memperkuat ekonomi lokal. Menggunakan metode pelatihan dan pendamipingan kiagatan ini menyasar masayarakat Desa Maman yang tergabung dalam kelompok ibu rumha tangga nelayan sebanyak 30 orang. Hasil dari program ini yang diukur dengan pengamatan menunjukkan adanya peningkatan keterampilan mitra dalam mengolah ikan air tawar sebesar $80 \%$. Hasil lainnya dari kegiatan ini adalah terciptanya dua jenis produk olaha/agroindustri ikan air tawar yaitu abon ikan dan stick tulang ikan.

Kata Kunci: pemberdayaan; agroindustri

\section{PENDAHULUAN}

Berbicara tentang potensi wisata yang ada di Kabupaten Sumbawa terdapat sebuah desa yang terletak lebih kurang $20 \mathrm{~km}$ sebelah Tenggara dari ibu kota Kabupaten Sumbawa. Desa ini bernama Desa Maman. Desa yang terbagi dalam tiga dusun ini termasuk dalam wilayah Kecamatan Moyo Hulu, sangat potensial menjadi desa ekowisata karena di dalamnya terdapat sebuah bendungan/waduk yang diberi nama Batu Bulan. Waduk ini selesai dibangun pada tahun 2002, dan pada waktu itu diresmikan oleh Presiden RI Megawati Soekarno Putri. Potensi besar yang dimiliki objek wisata Waduk Batu Bulan khususnya jika dikaitkan dengan konsep ekowisata, juga tertuang dalam hasil penelitian Masniadi et.al (2017). Salah satu poin penting dari hasil penelitian ini menyebutkan bahwa destinasi wisata Waduk Batu Bulan termasuk dalam destinasi ekowisata karena telah memenuhi prinsip dan kriteria ekowisata. Dalam penelitian ini Waduk Batu Bulan didentifikasi memilki potensi ekowisata setelah memenuhi prinsip dan kriteria ekowisata meliputi: (1) prinsip konservasi alam dan budaya (2) prinsip partisipasi masyarakat (3) prinsip ekonomi (4) prinsip edukasi (5) prinsip wisata.

Sampai dengan saat ini Waduk Batu Bulan tercatat sebagai bendungan terpanjang di Provinsi NTB, dengan panjang puncak bendungan total $2.750 \mathrm{~m}$. Dibangunnya Waduk Batu Bulan terutama untuk pengembangan jaringan irigasi dengan daerah layanan irigasi seluas $5.576 \mathrm{~km}^{2}$. Saat ini telah mampu mengairi area pertanian mencapai kurang lebih 5.100 Ha. Di samping berkontribusi di sektor pertanian Waduk Batu Bulan juga memeliki fungsi-fungsi lain yaitu memenuhi kebutuhan air minum ternak, pengendalian banjir, dan menjadi tempat pengembangbiakkan ikan tawar (Data Waduk Batu Bulan, survey awal tim di kantor Desa Maman, 2018).

Berkaitan dengan potensi kepariwisataan Waduk Batu Bulan yang dimiliki Desa Maman ini, ada permasalahan yang cukup menarik untuk disoroti. Secara factual, kegiatan penagkapan ikan yang dilakukan masyarakat (nelayan) setempat (khususnya Desa Maman) masih bersifat konvensional baik menggunakan pancing, jala dan atau alat lainnya. Hasil tangkapan ikan biasanya dalam jumlah yang banyak, tidak hanya ikan yang berukuran layak tangkap, tapi juga ikan yang berukuran kecil (belum layak tangkap). Kemudian implikasi lebih jauh dari banyaknya hasil tangkap ini, para nelayan menjual ikannya dengan harga yang relativ murah. Karena harga jual ikan yang murah, maka secara otomatis pendapatan para nelayan relativ rendah. Hal ini dilakukan karena nelayan setempat tidak punya pilihan lain, mengingat masih minimnya pengetahuan dan keterampilan mereka dalam hal pengolahan ikan agar lebih tahan lama dan memilki nilai tambah yang lebih besar. Berbicara dalam konteks peningkatan nilai tambah, ikan hasil tangkapan tentu saja memliki nilai tambah yang sangat rendah karena dijual secara mentah. Padahal jika tersentuh agroindustri, misalnya diolah terlebih dahulu menjadi produk olahan ikan (agroindustri), tentu akan semakin meningkat nilai tambahanya, yang 
berdampak pada peningkatkan harga jual yang secara otomatis meningkat pendapatan keluarga para nelayan di Desa Maman.

\section{METODE}

Merujuk pada permasalahan sebagaimana diuraikan pada bagian sebelumnya, maka metode yang digunakan dalam rangka menyelesaikan masalah merujuk pada hasil penelitian Masniadi et.al (2017) yang berjudul "Kajian Potensi dan Pengembangan Ekowisata Alam Di Kabupaten Sumbawa". Penelitian ini merupakan tindak lanjut dari kerjasama Lembaga Penelitian dan Pengabdian masyarakat (LPPM) Universitas Samawa (UNSA) dan Bappeda Kabupaten Sumbawa pada tahun 2017. Peneltian ini bertujuan untuk menyediakan informasi, dokumen dan basis data pada empat kecamatan sampel yang menjadi potensi ekowisata yaitu di Kecamatan Sumbawa, Kecamatan Tarano, Kecamatan Lunyuk, dan Kecamatan Moyo Hulu. Dari beberapa poin yang menjadi hasil penelitian ini, salah satunya berkorelasi erat dengan kegiatan ini, sehingga terlihat jelas bahwa kegaiatan ini merupakan hilirisasi dari kegiatan penelitian yang telah dilksanakan sebelumnya. Hasil penelitian menunjukkan bahwa di Kecamatan Moyo Hulu teridentifikasi ada enam objek wisata yang memenuhi prindip dan kriteria ekowisata yang salah satunya adalah Waduk Batu Bulan. Lebih jauh, dalam penelitian ini juga merekomendasikan beberapa strategi pengembangan kawasan Waduk Batu Bulan sebagai destinasi ekowisata yaitu:

1. Peningkatan promosi dan perluasan peluang pasar.

2. Peningkatan ekonomi lokal dan penguatan sumberdaya manusia

3. Dukungan kebijakan pemerintah setempat dalam pengembangan ekowisata

4. Pemberdayaan stakeholder untuk pengembangan ekowisata dan pelestarian lingkungan

5. Pemanfaatan lahan sesuai dengan potensi ekowisata untuk meningkatkan kontribusi secara ekonom bagi pengelola dan masyarakat

Hasil dan rekomendasi penelitian ini sangat relevan untuk dijadikan referensi dalam rangka mengembangkan potensi Waduk Batu Bulan. Terutama ketika menyoroti permasalahan minimnya pengetahuan dan keterampilan rumah tangga nelayan dalam hal pengolahan ikan agar lebih tahan lama dan memilki nilai tambah yang lebih besar. Maka untuk menjawab masalah ini dengan mengoptimalkan potensi bahan baku (ikan air tawar) yang dihasilkan Waduk Batu Bulan, rumah tangga nelayan harus deperkenalkan dan dilatih metode pengolahan ikan (agroindustri) yang bernilai tambah tinggi sebagai sarana peningkatan ekonomi lokal dan berkontribusi meningkatkan kesejahteraan masyarakat.

\section{HASIL DAN PEMBAHASAN}

\section{Pelaksanaan Kegiatan}

Kegiatan pelatihan dan pendampingan "Produksi Olahan/Agroindustri Ikan Air Tawar" merupakan program ketiga dari lima program utama yang direncanakan dalam Program KKN-PPM ini. Kegiatan ini dilaksanakan pada tanggal 22 April 2019. Kegiatan ini bertempat di Aula Serba Guna Desa Maman.

Kegiatan pelatihan dan pendampingan berjalan baik dan lancar, dihadiri oleh 30 orang peserta (ibu-ibu rumah tangga Desa Maman). Narasumber kegiatan ini adalah Wening Kusuma Wardani, MP 
(Dosen Prodi Agroteknologi). Kegiatan ini terbagi dalam dua sesi. Sesi pertama berisi penyampaian materi teori/konsep umum pengolahan/agroindustri ikan air tawar yang menggunakan bahan dasar ikan gabus waduk Batu Bulan.

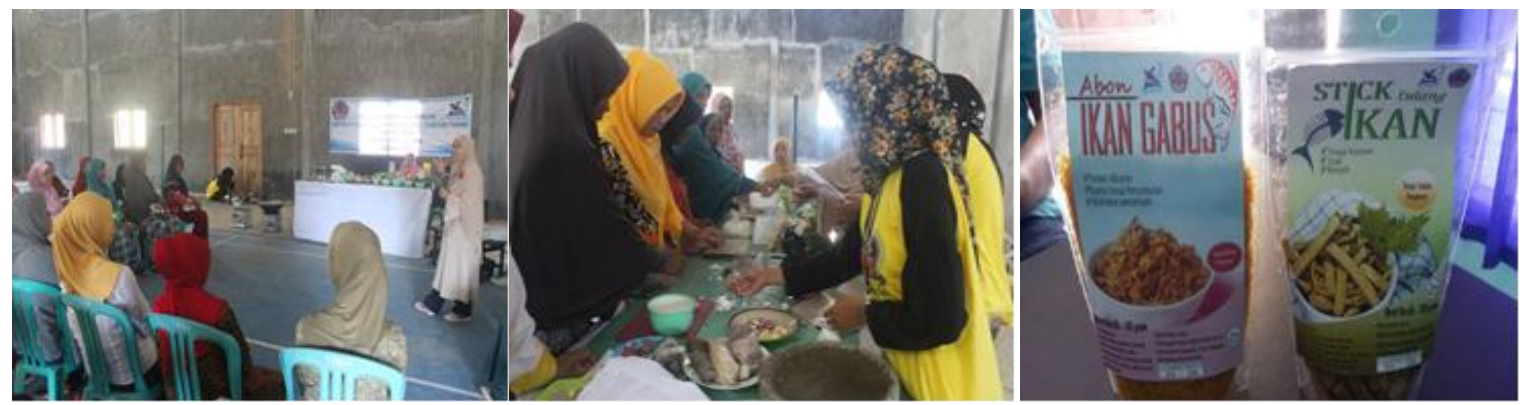

Gambar. Penyampaian Materi Pelatihan Produksi Olahan Ikan Air Tawar (kiri); Praktik Produksi Olahan Ikan Air Tawar (tengah); dan Produk Olahan Ikan Air Tawar (kanan)

Selanjutnya pada sesi kedua, dilanjutkan dengan praktikum pembuatan olahan ikan gabus waduk Batu Bulan. Dalam kegiatan ini, ikan gabus diolah menjadi dua produk yaitu "Abon Ikan" dengan bahan dasar daging ikan gabus dan "Stick Tulang Ikan" dengan bahan dasar tulang (sisa) ikan gabus. Peserta pelatihan dalam hal ini ibu-ibu rumah tangga sangat antusias mengikuti kegiatan praktikum. Pada bagian ahir sesi ini juga disampaikan kepada peserta tentang teknik pengemasan agar produk tahan lama. Sesi penutupan diahiri dengan penyerahan bantuan alat produksi berupa alat pengemasan dan panci presto ikan dari Tim KKN-PPM UNSA kepada ketua kelompok peserta pelatihan.

\section{Evaluasi Pelaksanaan Kegiatan}

Evaluasi pelaksanaan kegiatan ini dilaksanakan bertolak dari penilaian atas tingkat parisipasi dan penilaian atas tingkat keterampilan mitra sasaran. Pertama, dari sisi tingkat partisipasi mitra evaluasi dilaksanakan dengan cara menilai jumlah kehadiran mitra serta keaktivan mitra dalam kegiatan praktik. Hasil evaluasi menunjukkan bahwa $100 \%$ mitra hadir sesuai jumlah pserta yang direncanakan (30 orang). Kemudian semua peserta pelatihan sangat antusias dan aktif mengikuti kegiatan hingga akhir/penutupan kegiatan. Kedua, dari sisi keterampilan mitra setelah kegiatan berlangsung mitra sasaran sudah tgerampil dalam membuat olahan ikan air tawar produk abon dan sick tulang ikan hingga tahap pengemasan. Jika dikuantitatifkan keterampilan mitra sasaran mencapai 80\%, artinya 24 dari 30 orang mitra bisa dikatagorikan terampil.

\section{KESIMPULAN DAN SARAN}

Berdasarkan hasil kegiatan ini, maka dapat ditarik kesimpulan bahwa kegiatan ini telah berhasil meningkatkan pengetahuan dan keterampilan masyarakat Desa Maman (mitra sasaran) tentang metode pengolahan ikan (agroindustri) agar memiliki nilai tambah tinggi, sehingga dapat meningkatkan pendapatan masyarakat dan memperkuat ekonomi lokal. Mitra sasaran mampu menghasilkan produk olahan ikan berupa abon ikan dan stik tulang ikan.

Kegiatan ini mendapat respon positiv dari masyarakat khsusnya Desa Maman. Selanjutnya, sebagai saran/rekomedasi, perlu ada langkah-langkah strategis dari pemerintah Desa Maman untuk 
melanjutkan kegiatan ini secara lebih luas dan kontinyu agar pendapatan masyarakat (nelayan waduk Batu Bulan) Desa Maman terus meningkat, sehingga mampu mengangkat taraf hidup masyarakat Desa Maman.

\section{Ucapan Terima Kasih}

Penulis mengucapkan terima kasih kepada Direktorat Jenderal Penguatan Riset dan Pengembangan Kemenristekdikti yang telah member dukungan finansial sehingga program ini berjalan dengan sukses. Selanjutnya ucapan terim kasih kepada Lemabaga Penelitian dan Pengabdian Masyarakat (LPPM) Universitas Samawa (UNSA) yang telah mendukung dan memfasilitasi seluruh rangkaian kegiatan ini.

\section{DAFTAR PUSTAKA}

Bappeda Kabupaten Sumbawa, 2017. Rencana Pembangunan Jangka Menengah (RPJMD) Kabupaten Sumbawa Tahun 2016-2021. Bappeda Kabupaten Sumbawa

Masniadi, Rudi et.al, 2017. Kajian dan Potensi Pengembangan Ekowisata Alam Di Kabupaten Sumbawa. LPPM Universitas Samawa (UNSA).

Simanungkalit, Victoria br. et.al, 2015. Buku Panduan Pengembangan Wisata Hijau. Diterbitkan Oleh Kementrian Koperasi dan UKM, Republik Indonesia. 